\title{
Közszolgáltatások és térbeli koncentráció
}

\section{Public Services and Spatial Concentration}

ÖsSZEFOGLALÁs

Térgazdaságtani szempontból a versenyképesség felfogható a térségek népességmegtartó és tôkevonzó, illetve munkahelyteremtő képességének jellemzőjeként. Ennek szellemében a területi versenyképesség a meglévố és fenntartható infrastruktúrán, az elérhetô közszolgáltatásokon, valamint a meglévố foglalkoztatottsági színvonalon (és a mindezek által biztosított vonzó életkörnyezeten) is mérhetô.

A jelen tanulmány egyik alapkérdése az volt, hogy bizonyos közszolgáltatások fokozott jelenléte elôidézi-e a gazdaság térbeli koncentrációját. Ennek szellemében tanulmányunkban áttekintést kínálunk a közszolgáltatások tipizálásáról és a területi versenyképességhez kapcsolódó irodalmáról; konceptualizáljuk a területi tôketípusok és a közszolgáltatások kapcsolatát; majd a Magyarország vidéki településein végzett fơkomponens- és klaszteranalízis segítségével szemléltetjük a gazdasági koncentráció, a lakosság jóléte-jólléte és a közszolgáltatások térbeli elhelyezkedése közötti hasonlóságokat és különbözőségeket.

Journal of Economic Literature (JEL) kódok: H50, C18, H41, H75, R12

Kulcsszavak: közszolgáltatások, versenyképesség, koncentráció, fôkomponensés klaszterelemzés

\section{Summary}

From a spatial economic aspect, competitiveness can be considered an indicator of the region's ability to maintain its population, to attract capital and to create workplaces. According to this, spatial competitiveness can also be measured through the existing and sustainable infrastructure, the available public services

Szabó Tamás doktorjelölt, Pécsi Tudományegyetem, Regionális Politika és Gazdaságtan Doktori Iskola (tamas.szabo@transportresearch.net), KovÁcs EszTer doktorjelölt, Pécsi Tudományegyetem, Regionális Politika és Gazdaságtan Doktori Iskola (info@gipfeltext.com). 
and the current level of employment (and through the living environment granted by these indicators).

One of the central questions of this study was if the increased presence of certain public services induces the spatial concentration of the economic space. With this in mind, in our study we provide an overview of the types and the literature on the topic of spatial competitiveness of the public services; identify the types of spatial capital; and later run a principal component and cluster analysis on the Hungarian settlements (except the capital) in order to identify the territorial similarities and differences in economic concentration, the welfare and the existence and intensity of the public services.

Journal of Economic Literature (JEL) codes: H50, C18, H41, H75, R12

Keywords: public services, competitiveness, concentration, principal component and cluster analysis

A területi versenyképesség napjainkban számos aspektusból az elemzés tárgya, viszont a különbözó interpretációkból még hiányzik a terület lakónépességének életminôségét és esélyeit jelentôsen befolyásoló állami feladatellátás intenzitásának, a közszolgáltatások hozzáférhetôségének részletesebb, fejlesztési szempontú vizsgálata. Annak ellenére, hogy a versenyképességet az európai közgazdaságtani felfogásban a kibocsátás nagyságával mérik (Camagni-Capello, 2013), méltatlanul reked kutatási területen kívülre a nemzetgazdasági erôforrások endogenizálása.

A fiskális intézménymenedzsment szerint a közmenedzsment akkor válhat versenyképessé, ha a tulajdonosi szemléletból visszaköszönnek a tudatosság múködéshez köthetô dimenziói. Ennek megfelelóen a jó közmenedzsment a versenyképesség előfeltételei közé tartozik, és a múködtetésnek érték- és céltudatosnak kell lennie. A múködtetés során a módtudatosságot fontos alkalmazni, amelynek az a lényege, hogy a feladatellátásban a célok tisztázása és a megvalósításhoz használt programok szinergiája érvényesüljön. A képességtudatosság feltételezi a szervezet képességleltárát, amelynek révén a hiányosságok megszüntethetốk. A forrástudatosság pedig a mérlegszemléletúséget emeli ki a versenyképességet segítô tényezốk közül. A környezettudatosság a közremúködố partnerek kapcsolódási lehetôségére világít rá (Kovács, 2007), az utóbbi pedig értelmezhetố úgy is, mint a rendelkezésre álló belsố erôforrások kihasználása.

Ugyancsak a belsố erőforrások fontosságára hívja fel a figyelmet a pénzügyi közgazdász, aki a humán erőforrás, illetve az oktatás minôségi kritériumait, a „humán erőforrás bóvített reprodukcióját" jelöli meg a versenyképesség egyik alaptényezôjének (Lentner, 2007). A szerzố - a stabilitást garantáló pénzügyi konvergenciacélok mellett - a szakképzett munkaerô aktuális állapotának javításában látja a versenyképesség garanciáját.

A belsố tényezôs erôforrások külön befektetést nem igényelnek a nemzetgazdaság részérôl, de fontos, hogy a területi politika alkotói kiaknázzák a lakónépességben, illetve a térségekben rejló potenciált, mert egyfelôl csökkenti a nemzetgazdasági kitettséget, másfelôl pedig fejleszti a lokálpatriotizmust. Ugyanakkor gátat szabhat azoknak a veszélyes szocio-ökonometriai látens funkcióknak, amelyek a térszerkezet demográfiai, valamint erőforrásstruktúra-átrendezôdésé- 


\section{Tudományos múhely}

ért felelôsek. Az ilyen jellegú folyamatoknak szabhat gátat, ha az érintett térségek önkormányzatai kihasználják a térségek helyi erőforrásait és technológiai, valamint piaci elônyeit. A térségek belsố erőforrásainak észszerú kiaknázása, hatékony mozgósítása révén javítható azok potenciálja, és ezzel együtt a lakónépesség jóléte is (Camagni-Capello, 2013). A szerzôpáros empirikus kutatásában az alábbi versenyképességi faktorokat deklarálja:

- a helyi termelói aktivitást, a tradíciókat, valamint a képességeket és a különbözố know-how-kat;

- az egyes tôkefajták térben koncentrált rendszerét - mint például a társadalmi, illetve humán tôke -, hangsúlyozottan szinergikus múködési jelleggel;

- kulturális és értékrendi elemeket, amelyek képesek strukturálni és definiálni a helyi identitást, ideértve például a helyi termékek és szolgáltatások piacát;

- olyan szabályozórendszert, amelyben a törvényhozók (esetünkben a rendeletalkotó önkormányzat, illetve hatósági szervek) kiszolgálják a lakossági érdekeket.

Kétségtelen tény, hogy a fenti faktorok kevésbé tartoznak az operacionalizálható kategóriák sorába, de az bizonyos, hogy a fenti gyakorlat bevezetése eredményeként olyan multiplikátorhatás érhetô el, amely a lokális, NUTS3-as szint alatti területek gazdasági teljesítményének trendjében is mérhetô. Hazánk esetében az egyes térségek gazdasági pólusait azok ipartörténete és gazdaságföldrajzi helyzete determinálja. A belsố erôforrások mozgósítása a szocialista iparosítás fellegvárainak térségeiben különösen azon területek esetében válhat fokozottan indokolttá, ahol a gazdaságföldrajzi pozíció és az infrastruktúrával való ellátottság nem olyan kedvezô, mint például az M1-es autópálya mentén elhelyezkedô, korábbi iparvárosok tekintetében. Utóbbiakba a tôkebeáramlás már a rendszerváltás környékén intenzív volt, de az infrastruktúra-fejlesztésnek köszönhetóen a termelővállalatok száma is növekedett, amelynek eredményeként a munkaerópiac felpezsdült, illetve a munkaerố is mobilabbá vált (Siska-Szabó, 2015).

Jogosan merül fel a kérdés, hogy vajon milyen felzárkózási lehetôség jut azoknak a térségeknek, amelyek a betelepüló tôke látókörén kívülre szorulnak, mert a rossz infrastrukturális ellátottságuk vagy kedvezôtlen földrajzi helyzetük növeli a logisztikai költségeket.

A makro- és a térgazdaságtani közgazdászok versenyképességi nézetei azonos irányba mutatnak tehát: a nemzetgazdasági színtéren értelmezett és mért versenyképesség egyes elemei mikroszintú eredmények aggregációjával jönnek létre, és ezeknek alapja a helyi közigazgatási szinten teremtôdnek meg (Palotai-Virág, 2016). A nemzetközi szakirodalom a külsố forrásoknak kitett nemzetgazdaságok eseteinek vizsgálatakor tér ki a területi tôke fogalmára, amely értelmezésében két fô dimenziót javasol a fogalom körülhatárolására, ezek pedig a versengô és az anyagiasult javak jelenléte a vizsgált területeken. A versengó javak esetében a közgazdaságtan elkülöníti a tiszta közjavakat, ${ }^{1}$ a vegyes közjavakat, a magánjavakat, valamint ezeken túl egy köztes jószágot, az ún. klubjavakat (Nordhaus-Samuelson, 2012). ${ }^{2}$

$\mathrm{Az}$ anyagiasult javak kategóriája tartalmazza a tárgyiasult javakat (tangible goods), az immateriális javakat (intangible goods), valamint az ún. hard-soft java- 


\section{Tudományos múhely}

kat, ami az iménti kategóriák speciális elegye (Camagni-Capello, 2013). Utóbbiak tartalmazzák azokat a virtuális (digitális) vagy szolgáltatás jellegú javakat, amelyek a hazai közszolgáltatások gyakorlatában leginkább az e-közigazgatás egyes részeit foglalják magukban.

Figyelembe véve, hogy a közjavak elôállítása nem konkrét helyhez kötötten történik, illetve a finanszírozásuk tekintetében sem közigazgatási, sem területi értelemben nem egy helyen jelenik meg, továbbá a hozzáférhetôség intenzitása sem azonos, hatással van a területi versenyképességre, illetve ezen keresztül differenciál. Ezen tulajdonságok révén a közszolgáltatások hozzáférhetôsége befolyásolja a térségek lakónépességének jólétét és helybenmaradási hajlandóságát, valamint versenyképességi esélyeit.

Az állami feladatellátás és a tôke közötti kapcsolatot - közgazdaságtani értelemben - a társadalmi tôke biztosítja, ami „olyan cselekvési képességekre, nevezetesen a tulajdonra és a szakmai képességekre vonatkozik, amelyek a gazdasági élet területén más egyénekre gyakorolt befolyás révén elôsegítik bizonyos javak megszerzését" (Farkas, 2013:107). Ezen az interpretáción keresztül vizsgálva a közjavakat, közvetett kapcsolatot feltételezhetünk a közszolgáltatásokhoz való hozzáférhetôség és a területi versenyképesség, illetve a koncentráció között. Szociológiai értelmezésben a (társadalmi) tốke fogalmának konceptualizálása Pierre Bourdieu (1980) és James S. Coleman (1988) nevéhez fúzôdik, akik a tôke fogalmába szimbolikus erôforrásokat, képességeket és javakat is beemeltek. Vegyük észre, hogy a közgazdaságtani tôke - a társadalmi javak finanszírozásán keresztül - pont az összetett társadalmi hatások miatt el- választhatatlan a szociológiai értelemben vett társadalmi tôkétôl; habár ez utóbbi kategóriáit kevésbé lehet számszerúsíteni. Másrészt viszont a szerzók felhívják a figyelmet arra, hogy a társadalmi tôke fogalmában húzódó társadalmi aktivitás olyan tartós kognitív motívum lehet, amely képes mozgósítani egy térség egyes gazdasági aktorait.

A térségek versenyképessége szempontjából nem mindegy - ahogy a gazdasági tevékenység eloszlása esetében sem -, hogy a szimbolikus erôforrások miként súrúsödnek a térben, hiszen ezek karakterisztikája pozitív és negatív externáliaként szerepet játszik a térségek erôforrásainak hatékony aktivizálásában. Tehát - ahogy erre több tanulmány (Pénzes, 2013; Káposzta, 2014) rámutat - a gazdasági hátrányokat tompíthatja a humán tốke markáns és aktív jelenléte, ami a közszolgáltatások hiányára vagy kiesésére ${ }^{3}$ is megoldást nyújthat.

\section{A KÖZSZOLGÁLTATÁSOK DETERMINÁCIÓI}

A közszolgáltatások mint komplex állami feladatellátási kötelmek egy társadalom tagjainak életminôségét közvetlenül képesek befolyásolni a közösségi javak hozzáférhetôsége, felhasználhatósága révén. Szerepük a 19. század második felében kezdett az államigazgatáson belül kulcsfontosságúvá válni, amikor egyre több magánszolgáltatást emeltek át a versenypiaci múködésből a közigazgatási jog által szabályozott keretek közé.

A közszolgáltatások fogalmának magyarázata tekintetében a közigazgatási tudományokból érdemes kiindulni, de amikor ezt tesszük, rögtön azzal találjuk szemben magunkat, hogy a közigazgatás körén belül is különbözô megközelítések 
léteznek. A közgazdaság-tudomány fókuszában méretgazdaságossági szempontok állnak, míg a szociológia a közszükséglet, illetve a társadalmi jólét maximumát helyezi középpontba. A közigazgatás-tudomány az igazgatási feladatokra koncentrál, míg a jogtudomány - természetébôl fakadóan - a jogi szabályozottságot, illetve lefedettséget vizsgálja.

A fogalmi determinációt tartalmi szempontból Hoffman három szinten határozza meg, amely a legtágabb értelmezéstôl a legszúkebb lehatárolásig terjed. Legtágabb értelmezésbe sorolható minden olyan állami szolgáltatás, amelyet az állampolgárok alanyi jogon (adófizetési kötelmükért cserébe) részben vagy teljes egészében térítésmentesen igénybe vehetnek (pl. törvényhozás, bûnüldözési tevékenység stb.). A szúkebb értelmezés szerint, ezek az állampolgárok széles körének nyújtanak ellátást, és „nem minôsülnek egyoldalú, közhatalmi aktusnak". A legszúkebb értelemben vett közszolgáltatások közé sorolja azokat, amelyek esetében az állam - vagy a vele közszolgáltatási szerzôdést kötố jogi személy - tényleges, személyre szabott szolgáltatást nyújt (Hoffman, 2006). Utóbbiakat valamilyen jogosultsági vagy kedvezményezetti alapon veheti igénybe az állampolgár. Mindhárom kategória esetében egyaránt gyakori a veszteségfinanszírozás. Ennek értelmében az állami feladatellátást magára vállaló gazdasági társaság közvetlenül a szolgáltatáshoz kapcsolható veszteségét az állam köteles megtéríteni a szolgáltatónak. A veszteségfinanszírozás megítélésekor különbséget kell tennünk a különbözó ágazatokba tartozó közszolgáltatások között, amelyeknek sajátosságai természetüknél fogva határozzák meg a feladatellátási kötelezettséget átvállaló finanszírozási kereteket. Értelemszerúen más-más kategóriába sorolható az egészségügy és a közösségi közlekedés, mert míg elóbbi az emberi erőforrás minôségéhez szorosabban kötódik, addig utóbbinak a gazdasági haszna általában könynyebben számszerúsíthetố.

Hozzáférés szempontjából a közösségi jószágok csoportosítása szofisztikáltabban elvégezhetô, hiszen léteznek olyan, a közösséget kiszolgáló, társadalmi igényeket kielégító szolgáltatások, amelyek fogyasztásából a jogi személyek sem zárhatók ki. Ezek az ún. tiszta közjavak, mint például a közösségi színterek, parkok stb. Ezzel szemben a vegyes közjavak esetében bizonyos fogyasztói réteg kizárása túl költséges lenne, így a rendszerben megjelennek a potyautasok, akik ellátása a társadalom számára evidenciává vált. Ebbe a körbe tartozik például a szociális segélyrendszer összes eleme. A vegyes közjavak esetében elmondható tehát, hogy abba azok a nem tisztán versenypiaci kategóriájú szolgáltatások tehetôk, amelyek jellegüket tekintve társadalmi, szociálpolitikai vagy más célrendszer alapján szervezôdnek. Ez egyben felveti az elszámolhatóság kérdését, illetve az átláthatatlanság disszonanciáját, és magában hordozza a témával kapcsolatos döntések nehézségét. Ezt a kettôsséget egyfelôl a támogatások megítélése, a tevékenységek hatékonysági pressziója, másfelól a társadalmi-gazdasági szempontú minôségi célkitúzések jelentik.

Az állami feladatellátási kötelezettség tekintetében elmondható, hogy minden közszolgáltatásnak minôsül, amit a jogalkotó meghatározott eljárás keretében közszolgáltatásnak minősít. Fontos ismérv, hogy minden állampolgárnak alkotmányos alapjoga a közjavakhoz való hozzáférés, amelynek keretében az állam 


\section{Tudományos múhely}

gazdasági szerepet vállal többek között szociális, egészségügyi, oktatási, közlekedési, kulturális, energetikai területen. A kapcsolódó feladatellátást az állam egyetemleges közszolgáltatási szerzódés keretén belül átruházhatja gazdasági társaságokra, amelyek kötelesek a szerzôdéses feladatuk maradéktalan és kifogástalan ellátására, amelyért a piaci ár és a közszolgáltatásból fakadó és nyújtandó kedvezmények közötti árkülönbözetet, illetve az ebból fakadó gazdasági veszteséget az állam a közszolgáltatási szerzôdésben meghatározott feltételek szerint köteles megtéríteni. A közszolgáltatás nyújtása során az állam feladata - a szabályozó hatóságok közremúködésével - a piac szabályozása, a múködés ellenôrzése, a tevékenység finanszírozása.

A közszolgáltatások nem pusztán közvetett, hanem közvetlen módon is hozzájárulnak egy nemzetgazdaság vagy azon belül egy-egy térség gazdasági és humánpotenciáljához, és ezáltal versenyképességéhez. Ennek alapfeltételei a hatékony és gazdaságilag stabil (tehát fenntartható), a gazdaságot kiszolgáló múködés és a szolgáltatók közötti versenyhelyzet megteremtése. Ennek révén tisztul a piaci verseny, és javul a szolgáltatások minôsége és hatékonysága. Ennek szellemében érdemes azokra a szolgáltatásokra fókuszálni, amelyek a nemzetgazdaság szempontjából nagyobb volumenú erôforrásokat kötnek le, és hatékonyság szempontjából jelentôs források allokációját kívánják. Továbbá azokra is hatványozott figyelmet kell fordítani, amelyek nemzetgazdasági szempontból stratégiai fontosságúak, és a nyitott vagy nyitásra váró piac miatt nemzetközi versenytársak belépésére számíthatnak. Utóbbi piacok megóvása azért is kiemelkedô fontosságú, mert egy-egy nemzet esetében általában hálózatias (gyakran egész országot lefedô) és generációkon átívelố teljesítményt manifesztáló (akár know-how-ban, akár infrastruktúrában megjelenô) teljesítményrôl van szó. Ugyancsak kiemelt figyelmet érdemelnek azok a közszolgáltatások, ahol a foglalkoztatottság nagy, tehát jelentôs munkaerôpiaci kitettséggel rendelkeznek.

A közszolgáltatásokba történô beruházás azért is megtérül, mert a minôségi közszolgáltatások több szinten is hozzájárulnak a területi versenyképességhez:

- A helyi önkormányzatok adó- és egyéb kedvezmények formájában megteremtik a lehetôséget a betelepülố tốke vagy a meglévố vállalkozások számára a hatékonyabb múködésre, ami elôsegíti azok magasabb foglalkoztatottsági mutatókkal, illetve magasabb termelékenységgel - azaz nagyobb iparúzésiadó-alappal történố múködését.

- A térségekben múködô vállalkozások és a lakónépesség számára nyújtott magasabb hozzáadott érték szélesebb múködési terület és hozzáférhetôség révén segíti elố az érintettek versenyképességét az adott lokációban és nemzet(közi) gazdasági színtéren egyaránt.

- Idesorolható minden olyan közszolgáltatás, amely hat a nemzetközi versenyben való megmérettetés eredményességére: ilyen például a logisztikai és szállítmányozási piac valamennyi résztvevôje, illetve a felsôoktatási intézmények mindegyike (Kiss, 2011).

Figyelembe véve a közszolgáltatások erôforrásigényét (illetve az ebből fakadó munkaerópiaci hatásokat), és azt a tényt, hogy másodlagos (kiszolgáló) szerepük révén nagymértékben szolgálják a nemzetgazdaság versenyképességének egészét, a rájuk való fókuszálás indokolt. 
A NEMZETGAZDASÁG BELSỐ ERÔFORRÁSAI

$\mathrm{Az}$ endogén (belsố tényezốkön alapuló) növekedési elmélet a területi versenyképességgel kapcsolatos kutatások fókuszpontját a régiók közötti összehasonlításokról a belsố területi kapacitások mérésére helyezi át. Teszi ezt abból a megfontolásból, hogy a belsố kapacitások, erôforrások együttmúködéssel és szinergiával történô alkalmazása produktívabb, mint a szétszórt támogatási rendszer, és ezt tükröznie kell a regionális versenyképesség vizsgálati szempontjainak, mérési módszereinek is.

Az elmélet szerint a térségek belsố erôforrásai közül a helyben meglévố gazdaságföldrajzi és „socialeconomic” adottságokat kell felismerni és hatékonyan mozgósítani a területi fejlôdés érdekében. Tömörebben: a területek kondícióinak meghatározó befolyása van a gazdasági tevékenységek jövedelmezôségére, illetve ezen keresztül a lokáció versenyképességére (Bodnár, 2013).

Meglátásunk szerint a számos kutató (Chapain-Clifton-Comunian, 2013; Capello, 2012) által képviselt irányvonal, amely a tudásból, illetve az innovációból eredezteti az endogén növekedést, csak akkor lehet igaz egy-egy konkrét lokáció esetében, ha ennek a tudásnak létezik munkaerópiaci szempontból releváns felvevôbázisa, illetve a keletkezett termékeknek, szolgáltatásoknak megfeleló piaca. Tehát csak addig létezhet az innovációalapú, tudásközpontú versenyképesség az adott térségben, amíg el nem éri a tudásalapon szervezôdött populáció létszáma azt a piachoz képest kritikus tömeget, ami vagy elvándorlást, vagy tevékenységáthelyezést eredményez. Még ha ez aggregált országos adatsorokban nem is jelenik meg, de bizonyos területekrôl elvándorlást indíthat meg, míg más, befogadó területeken fennáll annak a veszélye, hogy az adott gazdasági tevékenységhez kapcsolódó haszonból az érintett területi-közigazgatási egység nem vagy csak kismértékben részesül. Ezzel szemben a belsố tényezốs növekedéselmélet fejlesztéspolitikai szempontból fontos aspektusnak tartja a fenntarthatóság kérdéskörét, hiszen az emberi erôforrás és az infrastruktúra egyidejú fejlesztésétôl várja el, hogy - a multiplikátorhatásokon keresztül - fokozza a keresletet, illetve a termelékenység javítására legyen képes (Miklós-Molnár, 2012). Hasonló álláspontot képvisel Rechnitzer is, aki szerint a regionális potenciált az endogén források jellemzói determinálják (Rechnitzer, 2002).

A jelen tanulmány szerzôi a tốkepotenciált - azaz a rendelkezésre álló termelôbázisokat, illetve tốkét - az alábbi versenyképességi tényezôk szerint csoportosítják (1. táblázat).

A regionális kutatások számos esetben próbálják összefogni azokat a szerteágazó és komplex tényezóket, amelyek vizsgálatba vonása révén a térségek versenyképessége mérhetố. A területi tốke dimenzióinak hazai interpretációit vizsgálva (Jóna, 2013) látható, hogy a közjavak, illetve közszolgáltatások alacsony rivalizálás mellett vehetốk igénybe, de az eredeti területitốke-modell (Camagni-Capello, 2009) nem tér ki a közjavak és a versenyképesség kapcsolatának elemzésére, viszont axiómaként is értelmezhetô a közszolgáltatások hozzáférhetôségének és a lakónépesség versenyképességének kapcsolata. Ugyanis a térben koncentrálódó potenciál elszívja a perifériatérségekbôl a termelési tényezôket - amelyek közül leginkább mobil 
1. táblázat: A versenyképességi tényezôk és a közszolgáltatások kapcsolata

\begin{tabular}{|c|c|c|}
\hline & Tényező megnevezése & Konceptualizálás \\
\hline I. & A munkaerô jellemzôi & $\begin{array}{l}\text { Exogén tényezô - de egyes kutatók endogén tényezôként } \\
\text { fogják fel - , ahol a hangsúly a munkaerôpiaci korösszetételen } \\
\text { és képzettségi szinten van. Itt hívjuk fel a figyelmet arra, hogy } \\
\text { az iskolarendszer fôkként állami feladatellátási körbe tartozik, } \\
\text { tehát a közoktatási, szakképzési és felsôoktatási rendszerekhez } \\
\text { való hozzáférés közszolgáltatási aspektus. }\end{array}$ \\
\hline II. & $\begin{array}{l}\text { Infrastrukturális jel- } \\
\text { lemzốk }\end{array}$ & $\begin{array}{l}\text { A térségben rendelkezésre álló - részint állami, részint ön- } \\
\text { kormányzati fenntartású vagy gondozásban lévố - területek } \\
\text { és felépítmények, amelyek gazdasági potenciált foglalnak } \\
\text { magukban. }\end{array}$ \\
\hline III. & Földrajzi helyzet & $\begin{array}{l}\text { Exogén változó, ahol a területi versenyképességre való hatás } \\
\text { adott, illetve amennyiben elônytelen, úgy ez csak fejlesztés- } \\
\text { politikai beavatkozással tompítható. (Ilyen intézkedés lehet } \\
\text { például a közlekedési infrastruktúra fejlesztése, kiemelt } \\
\text { beruházások stb.) }\end{array}$ \\
\hline IV. & $\begin{array}{l}\text { Szociokulturális } \\
\text { adottságok }\end{array}$ & $\begin{array}{l}\text { A tárgykör pénzben közvetlenül nem kifejezhetô, de mégis } \\
\text { olyan potenciált hordoz, aminek gazdasági vetülete is létezik. } \\
\text { Hatást gyakorol a terület népességmegtartó erejére, illetve } \\
\text { egy térség populációjának a munkához való hozzáállására. } \\
\text { Ennek ápolása és fejlesztése - nagyrészt - szintén az állami } \\
\text { feladatellátás körébe tartozik. }\end{array}$ \\
\hline V. & Piaci kapcsolatok & $\begin{array}{l}\text { Kereslet-kínálati tényezôk, amelyek a szinergikus piaci } \\
\text { mechanizmusokra és a fizetôképes keresletre építenek. Ide } \\
\text { sorolnánk be azokat az állami vagy önkormányzati kezde- } \\
\text { ményezéseket, amelyek ennek elôsegítését szolgálják (pl. } \\
\text { a versenyképesség fejlesztésére irányuló állami operatív } \\
\text { programok, inkubációs programok, települési vagy kistérségi } \\
\text { együttmúködések stb.). }\end{array}$ \\
\hline VI. & $\begin{array}{l}\text { Döntési-intézményi és } \\
\text { hatalmi rendszer }\end{array}$ & $\begin{array}{l}\text { A jogalkotás területi hatályát, illetve hatását hangsúlyozzák a } \\
\text { szerzôk, illetve az állampolgárok és vállalkozások ügyintézéssel } \\
\text { kapcsolatos kiszolgálását, a térségek komplex jogi környezetét } \\
\text { emelik be a tôkefogalomba. }\end{array}$ \\
\hline
\end{tabular}

Forrás: Saját szerkesztés

a humán erôforrás -, ami konzerválja az érintett területek gazdasági és humánpotenciáljának kedvezôtlen helyzetét. Ez törvényszerúen együtt jár a gazdaság szerkezetének tercierizálódásával, azonban települési szinten gondot okozhat a nagymértékú elvándorlás, de az is, hogy bizonyos néprétegek munkalehetôség, képzettség, kielégító jövedelem és lehe- tôségek hiányában a hátrányos helyzetú területeken rekednek (Kovács, 2016).

A térgazdaságtani értelemben vett erôkoncentrációs elméletek egyike a centrum-periféria modell (Wallerstein, 1983), amelyet számos hazai szerzố is feldolgozott. A centrum-periféria modellben a térnek két pólusa létezik (Nemes Nagy, 2009). Eszerint a centrum pozitív, 
nagy gazdasági és társadalmi pontenciált magában hordozó, azokat halmozó területi egység, tekintet nélkül a földrajzi értelemben vett elhelyezkedésétôl. Ezek karakterisztikáját befolyásolja a közszolgáltatások, közintézmények jelenléte, illetve azok hozzáférhetôségének intenzitása, ami leginkább a közlekedési infrastruktúra kiépítettségétôl függ.

Persze a területi egyenlótlenségek nem merülnek ki néhány dimenzió vagy indikátor elemzése által nyújtott válaszban, mert a szociális és gazdaságtani ismérvek együtt, egy idóben vannak jelen, és fejtik ki hatásukat a területi egyenlótlenségek vonatkozásában (Obádovics-Buder-Kulcsár, 2013). A szegénység nemcsak pénzügyi, anyagi síkon manifesztálódik, hanem emellett a közjavakhoz való hozzáférés szúkösségében is megjelenik. Utóbbi hatását értelemszerúen tompítja a gazdasági jólét, ami a közszolgáltatások hiányával ellentétes irányba hat. Mindez azt sejteti, hogy a centrum-periféria relációk markánsan meghatározzák a térgazdaságtani és demográfiai folyamatok jelenét és jövôjét, újraértelmezve ezzel egy adott térség közgazdaságtani helyzetét.

\section{TÉRELEMZÉS}

A térgazdaságtani szakirodalom a regionális versenyképességi vizsgálatok során az egy fôre jutó GDP-t mint eredményváltozót vizsgálja, és számos egyéb magyarázó változót figyelembe vesz a térségek versenyképességi rangsorolása során (Pénzes, 2013). Ezt a módszertant elôszeretettel alkalmazzák a NUTS3-as vagy az alatti területi egységekre is, miközben a terület lakónépességének jóllétére kiható soft tényezóket nem tartják szem előtt. Tehát érdekes kutatói kérdés, hogy mi- ként lehetne javítani a térségek jóllétét, gazdaságát és foglalkoztatottságát a közszolgáltatások javításán keresztül, és viszont: a gazdaság térbeli koncentrációja és a humán erôforrás jellemzói miként hatnak vissza a közszolgáltatási igényre, valamint annak jellemzőire; de feltárandó a lakónépesség jóllétének gazdaságra gyakorolt hatása is.

A fentiek szellemében célkitúzésünk annak a kérdéskörnek a minél átfogóbb vizsgálata, hogy mennyire jár együtt, vagy éppen mennyire különül el az egyes települések esetében a közszolgáltatások, a humán adottságok, illetve a gazdasági potenciál térbeli koncentrációja a különbözô területi determinációk mellett. Ennek megfelelôen a célmeghatározást követố elsố lépésként kigyújtöttünk valamennyi olyan általunk elérhetô változót (elsô körben csupán tartalmi szempontok alapján), amelyek jellemezhetik és differenciálhatják az egyes területi egységeket társadalmi-gazdasági helyzetük és közszolgáltatásokkal való ellátottságuk szerint - a lehetô legtágabb értelemben (lásd 1. ábra). Elôzetesen azon szempontból kategorizáltuk, hogy azok meglévô, a településvezetés és közszolgáltatás-szervezés szempontjából külsố adottságként kezelhetô (gazdasági, foglalkoztatottsági vagy demográfiai) szempontok, vagy az ágazati, illetve területfejlesztési politika által is közvetlenül befolyásolhatók (infrastruktúra-hálózati közszolgáltatások, szociális ellátás, oktatás, egészségügy, kultúra és közigazgatás). Az ágazati megközelítés megfelelô kiindulópontnak tûnt.

Elsố körben 475, települési szinten is elérhetố mutató felelt meg ennek a szempontnak. Mivel ez az adattömeg hatalmas, vagy képi megjelenítésre alkalmatlan, adatredukciós módszerre (faktor- vagy 


\section{Tudományos múhely}

fốkomponens-elemzésre) volt szükség (Székelyi-Barna, 2002). Így az egymással összefüggó mutatókból kisebb számú faktort nyerünk, amelyek alapján képesek leszünk a települési szintú adatok típusainak és ezzel együtt jellemzô változóértékeinek a meghatározására, feltárására is a klaszteranalízis segítségével. Ha az alapvetô problémákat és azok összefüggéseit ezzel a módszerrel feltártuk, véleményünk szerint akkor lesz lehetôségünk a továbbiakban ezek, illetve az adott település (majd térség) jellemzóit, a - jelen vizsgálat eredményében is tükrözôdô - településhierarchiát és az esetleges települések közötti feladatmegosztást (specializációt) is figyelembe véve, közszolgáltatás-fejlesztési javaslatok megfogalmazására.

Figyelembe vettük, hogy a faktor/ fókomponens- és klaszteranalízisbe kizárólag magas mérési szintú változók kerülhetnek (Sajtos-Mitev, 2007), illetve kiküszöböltük az igen szélsôséges vagy véletlenszerú eloszlást követố változók nagy részét, így az adatredukciót 177 változó mentén kezdtük futtatni. (A csupán módszertani okokból kiesett, de nyilvánvalóan nagy kifejezôerôvel bíró változókat területi egységenként is besoroltuk, így a statisztikai vizsgálat eredményei ezekkel kontextusában - például járásonként, megyénként, agglomerációnként - is kiegészíthetôek a késôbbi kutatások során.)

A nagyszámú változó vizsgálata mellett - a területi kiegyenlítődés és az esélyegyenlôség szempontjait is szem elôtt tartva - célunk volt továbbá az is, hogy figyelmünk a legkisebb településre is kiterjedjen, így a vizsgálat egységeiként Magyarország 3154 vidéki települését választottuk. A kiugró adatok elkerülése érdekében a jelen vizsgálat nem terjed ki Budapestre, amit az is indokol, hogy a fóváros, illetve a Kö-
zép-Magyarország régió már a kétezres években elérte az Európai Unió fejlettségi átlagát, például az egy fớre esô, vásárlóerô-paritáson mért GDP tekintetében. (Emiatt számos területi kiegyenlítódést célzó fejlesztési forrásra sem pályázhat már, de feltételezhetjük azt is, hogy a gazdasági infrastruktúra és a gazdaság fejlôdését elôsegító intézményrendszer, mint például startupokat támogató alapok, pénzügyi szolgáltatások, oktatás-kutatás és az egyéb, közvetlenül üzleti szolgáltatások már vannak annyira fejlettek, hogy a gazdaság fejlốdése további állami beavatkozás nélkül is kedvezố irányt vesz.) A fốváros a legtöbb gazdasági jellemzô mentén annyira eltér a vidéktôl, hogy annak fejlódése külön vizsgálat tárgyát kellene hogy képezze. Pest megyét azonban nem vettük ki a vizsgálatból, tekintve, hogy a terület maga is heterogén (Tipold et al., 2015). A fốvárost leszámítva az egyéb (közepes és nagy-) városok vizsgálatban maradását indokolja egyrészt a vizsgálat célja, amely nem csak és nem elsôsorban a leghátrányosabb helyzetú vagy a legkisebb településekre terjed ki.

A városok, községek, kistelepülések, aprófalvak összehasonlíthatóságának problémáját nagyrészt népességszámra arányosított viszonyszámok képzésével és használatával küszöböltük ki. Mindemellett magát a népességszámot nem vontuk be a fö́komponens- és klaszterelemzésbe. (Ennek ellenére - mint látni fogjuk - a kialakult csoportok népességszám alapján is igen jól körülírhatók.) Ezzel az volt a célunk, hogy érzékeltessük, hogy melyek azok a gazdasági jellemzók vagy szolgáltatások, amelyek a népességnél is jobban koncentrálódnak a térben, és ezáltal hol teremtôdik meg a lehetôsége a további agglomerációs elônyök megjelenésének és tovagyưrúzésének, és hogy ezzel szemben hol keletke- 
zik vákuum, ellátatlan néptömegek vagy szegény térségek, ahol szolgáltatás-, illetve gazdaságfejlesztésre, vagy legalább a közeli központok elérhetôségének biztosítására van szükség. (A módszer hátránya viszont az, hogy a legkisebb, elsôsorban 100 fó alatti települések esetében igencsak felfelé torzíthatnak ezek a mérôszámok, amenynyiben bizonyos típusú szolgáltatásból vagy méretú vállalkozásból egy vagy néhány jelen van a településen.)

\section{A vizsGálat EREDMÉNYEI}

Az adatredukció tekintetében a fốkomponens-elemzés bizonyult hatásosnak. A vizsgálat többszöri lefuttatása után és a nem megfelelóen aggregálható mutatóktól lépésenként megszabadulva 101 megórzött, 8 fókomponensre megfelelóen illeszkedô változó maradt meg, és az így keletkezett fókomponensek az eredeti változók információtartalmának összesen 59,5\%-át ôrizték meg, aminek a magyarázóértékét elfogadtuk. A kialakult fókomponensek azonban nem elsốsorban az elôzetes, külsô-belsố tényezóket vagy ágazati tagozódást követték, hanem azok sokkal inkább függenek össze a településhierarchiával, illetve az adott jellemzó vagy szolgáltatás által érintett korcsoport vagy gazdasági tevékenység adott településen való meglétével vagy hiányával. Például az oktatás ágazata három különbözó fókomponensre „esett szét”: alapfokú oktatásra (amelybe bekerültek a körzeti szintú egészségügyi ellátások is), középfokú, valamint felsôoktatásra. Ez egyrészt következik a vizsgálat módjából, de egyben rávilágít a területi szemlélet szükségességére is. Ellenben a „Szegénység és a rászorulókat támogató intézményrendszer" fốkomponens nagyban érinti a munkanélküliséggel kapcsolatos és demográfiai tényezóket, de számos infrastrukturális elemet és szinte a teljes szociális ellátást is felöleli (1. ábra).

\section{1. ábra: Fökomponensek az elözetes koncepció tükrében}

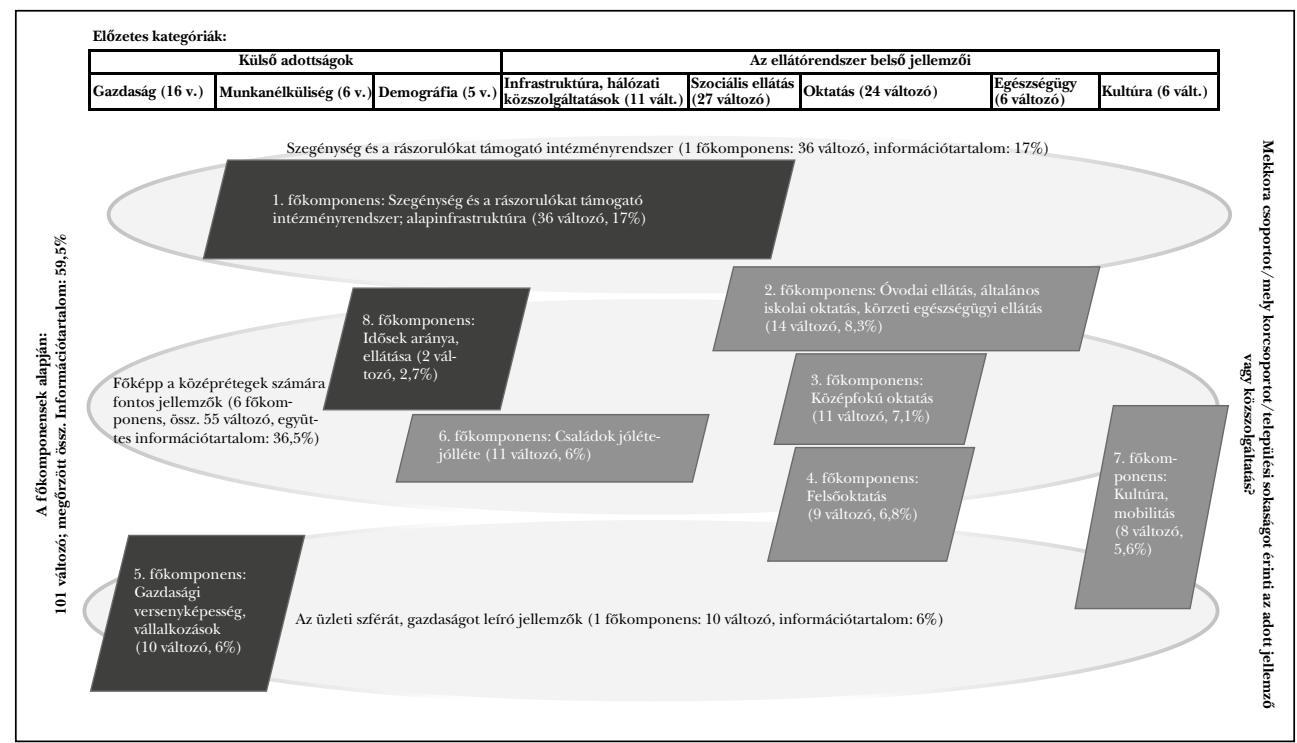

Forrás: Saját vizsgálat a KSH (2015, 2017) és a TEIR 2017-es adatai alapján 
A nyolc, viszonylag jól interpretálható fókomponens már elég jól kezelhetô ahhoz, hogy azokon klaszteranalízist hajtsunk végre a települések kategóriákba sorolása és ezek mentén történố nyolcdimenziós jellemzése érdekében. Tekintettel a viszonylag nagy adatállományra és még így is meglehetôsen sok dimenzióra, ${ }^{4}$ az iterációs K-Means Cluster-eljárást alkalmaztuk az SPSS-programcsomag segítségével (Obádovics, 2009). A módszer kiszámítja a dimenziók magpontjait, és az azokkal kapcsolt elemeket mindaddig rotálja, amíg a klaszterközéppontok nem stabilizálódnak.

\section{2. táblázat: A fókomponensek és az általuk összefogott változók}

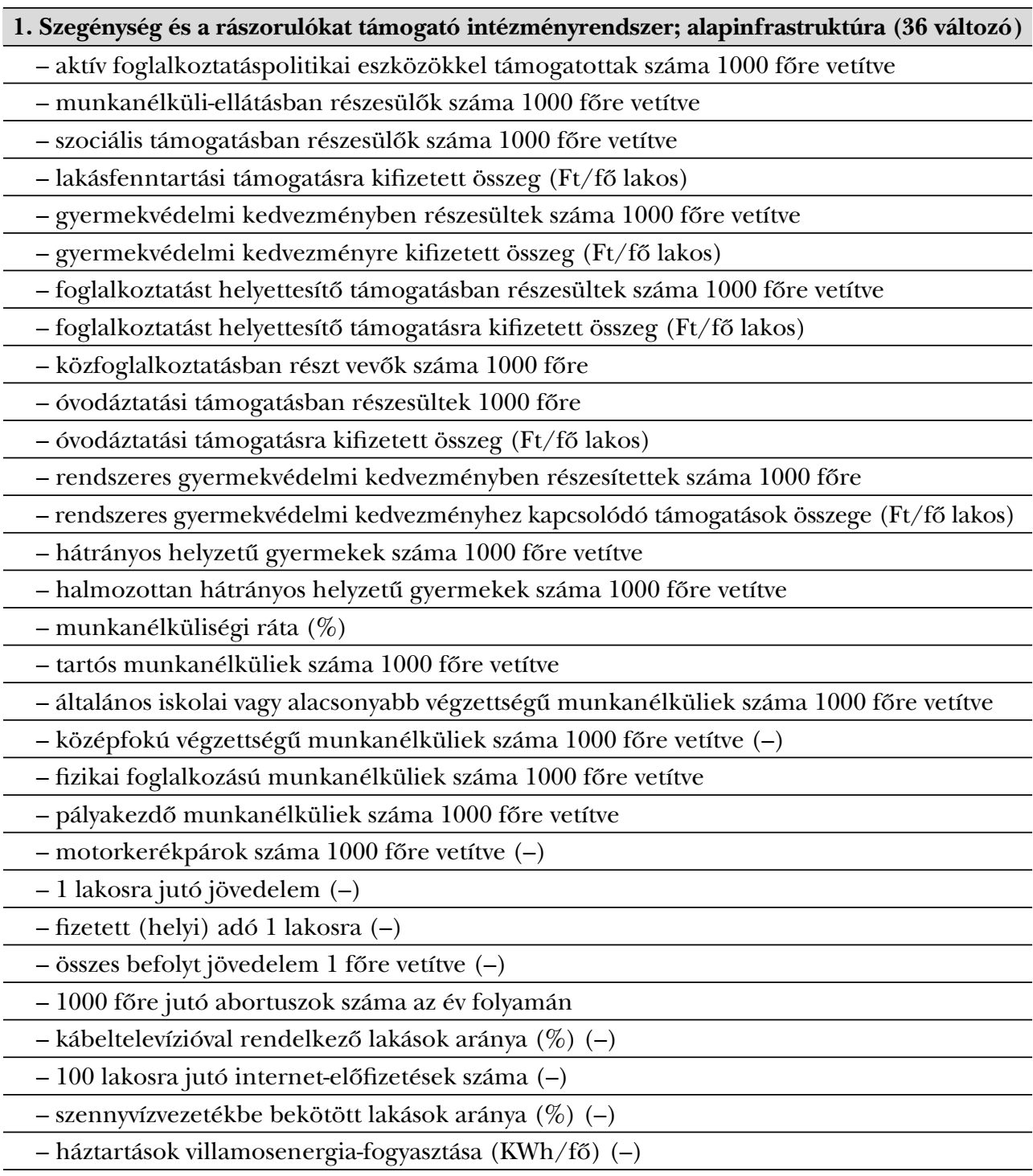




\section{Tudományos mühely}

- gázfogyasztó háztartások száma 100 lakásra vetítve (-)

- internettel rendelkezó általános iskolák aránya (\%)

- 1 általános iskolára jutó számítógépek száma

- 1 középfokú oktatási intézményre jutó számítógépek száma

- 100 före jutó telefonvonalak száma

- könyvtárak 1000 főre jutó száma

\section{2. Óvodai ellátás, általános iskolai oktatás, körzeti egészségügyi ellátás (14 változó)}

- 1000 före jutó szakápoló

- 1000 fốre jutó védônố

- 1000 lakosra jutó házi és gyermekorvosok száma

- 1000 lakosra jutó háziorvosok száma

- óvodai férôhelyek kihasználtsága (\%)

- 1000 fốre jutó óvodai férôhelyek száma

- 1000 fớre jutó óvodás gyermekek száma

- 100 óvodásra jutó óvópedagógusok száma

- 100 tanulóra jutó általános iskolai osztálytermek száma

- általános iskolák száma 1000 fốre vetítve

- általános iskolai tanulók száma 1000 fốre vetítve

- általános iskolai pedagógusok 100 tanulóra vetített száma

- napközi ellátásban részesüló általános iskolai tanulók száma 1000 fốre vetítve

- bejáró általános iskolások aránya (\%)

\section{Középfokú oktatás (11 változó)}

- középiskolák száma 1000 fŏ́re

- középfokú oktatási intézményben tanulók száma 1000 fốre

- gimnáziumi tanulók száma 1000 före

- szakközépiskolai tanulók száma 1000 fốre

- sikeres érettségi vizsgát tettek 100 diákra jutó száma

- 100 diákra jutó középiskolai pedagógus száma

- szakiskolák száma 1000 fớre vetítve

- középfokú oktatási intézmények száma 1000 fốre vetítve

- szakiskolai tanulók száma 1000 fốre

- 100 fő́re jutó szakiskolai tanárok száma

- bejárók aránya a középfokú oktatásban (\%)

\section{Felsôoktatás (9 változó)}

- nappali tagozaton felsôfokú szakképzésen részt vevô diákok száma 1000 fốre vetítve

- levelezô tagozaton felsôfokú szakképzésen részt vevô diákok száma 1000 fớre vetítve

- felsőfokú szakképzésen részt vevô diákok száma 1000 fớre vetítve

- nappali tagozatos egyetemi és fóiskolai hallgatók száma 1000 fớre vetítve

- levelezố tagozatos egyetemi és fốiskolai hallgatók száma 1000 fốre vetítve 


\section{Tudományos mühely}

- egyetemi és fôiskolai hallgatók száma 1000 fốre vetítve

- egyéb (nem települési) könyvtárból kölcsönzött könyvek éves száma 1 fŏre vetítve

- egyéb (nem települési) könyvtárba beíratkozottak száma 1000 fő́re vetítve

- kollégiumban lakó felsôoktatási hallgatók száma 1000 fớre vetítve

\section{Gazdasági versenyképesség, vállalkozások (10 változó)}

- legalább 10 fớt foglalkoztató regisztrált vállalkozások 1000 fốre jutó száma

- 1000 fốre jutó tehergépjármúvek száma

-1 fớre jutó hozzáadott érték (Ft)

- 1 fốre jutó bérköltség (Ft)

- 1 fớre jutó kibocsátás $(\mathrm{Ft})$

-1 fốre jutó fizetett adó (Ft)

- a vállalkozások 1 lakosra vetített bevétele $(\mathrm{Ft})$

- múködő vállalkozások 1000 fốre jutó száma

- múködô társas vállalkozások 1000 fốre jutó száma

- legalább 10 fốt foglalkoztató társas vállalkozások 1000 fốre jutó száma

6. Családok jóléte, jólléte és az ehhez kapcsolódó közszolgáltatások (11 változó)

- települési önkormányzat által kiépített út hossza $\left(\mathrm{m} / \mathrm{km}^{2}\right)$

- gyermekorvos által ellátott esetek száma a 14 éves kor alatti gyermekek számára vetítve

- 1000 gyermekre jutó gyermekorvosok száma

- idôskorúak nappali intézményeinek kihasználtsága (\%)

- szociális intézmények kihasználtsága (\%)

- bölcsôdei férôhelyek 1000 fốre jutó aránya

- bölcsôdés gyermekek 1000 fốre jutó aránya

- bölcsốdei férôhelyek kihasználtsága (\%)

- 100 bölcsốdésre jutó nevelốk száma

- bölcsốdék száma 1000 fốre vetítve

- népsúrúség (fö $/ \mathrm{km}^{2}$ )

\section{Kultúra, mobilitás (8 változó)}

- 100 fốre jutó lakások száma

- települési könyvtárból kikölcsönzött könyvek száma 1 lakosra

- települési könyvtárba beiratkozottak 100 fóre jutó száma

- közmúvelôdési intézmények száma 1000 lakosra

- civil, nonprofit szervezetek 1000 lakosra vetített száma

- (helyi) adót fizetố népesség aránya (\%)

- teljes vándorlási különbözet (ezrelék) (-)

- állandó vándorlási különbözet (ezrelék) (-)

\section{Idôsek aránya, ellátása ( 2 változó)}

- nyugdíjban részesültek 1000 lakosra vetített száma

- 65 éven felüliek aránya

Forrás: Saját vizsgálat a KSH (2015, 2017) és a TEIR 2017-es adatai alapján 


\section{Tudományos múhely}

A kezdeti iterációk során világossá vált (akár több, akár kevesebb klaszterszámot előzetesen meghatározva), hogy bizonyos települések jellemzőit, kiugró értékeit közelebbrôl is szemügyre kell venni, mert bizonyos klaszterek elemszáma túl kicsinek tûnt. Hétklaszteres bontásban külön klasztert alkotott például a mindössze 12 fôt számláló Tornabarakony, ahol a meglévố infrastrukturális létesítmények mindössze ilyen kevés fốre mint vetítési alapra oszlottak el, és ezért irreálisan magasnak túntek. De az elvándorlás is szélsôségesen magas értéket vett fel a településen a 2015-ös évben. Következésképpen ez a klaszter „kimagasló jólét” képét mutatta mind az 1. (szegénység, illetve annak hiánya), mind pedig a 7. (kultúra, mobilitás) fôkomponens mentén, ami nyilvánvalóan nem tükrözi a valóságot. Kirajzolódott egy olyan hatelemú, többnyire kistelepüléseket (Tésa, Óbudavár, Teresztenye, Komlóska, Újlengyel és Nagypáli) tartalmazó klaszter is, amelynek elemei az 5. fôkomponens, a gazdasági versenyképesség, vállalkozások dimenziója mentén mutattak kimagaslóan jó értékeket, míg a többi dimenzió ezt nem indokolta. Néhol felmerül az a gyanú, hogy bizonyos vállalkozásokat csak az alacsony kulcsú vagy nem lévô helyi adó miatt jelentettek be az adott településre, de valójában nem itt van a vállalat múködésének központja. Megvizsgálva a településekhez tartozó mért mutatóértékeket, azok elhelyezkedését és a róluk elérhetô egyéb információkat, az elôbbi négy települést és Tornabarakonyt elhagyva megismételtük a vizsgálatot. Azonban Újlengyel és Nagypáli az így módosított klaszterelemzésben is külön csoportot alkotott, így végül ezeket is mellőztük. Mivel a fentiek Magyarország 3155 településéból csak néhányat érintenek, viszont velük együtt rendkívül ellentmondásos, nyilvánvalóan téves klaszterstruktúra alakulna ki, az érintett összesen 7 települést kizártuk a vizsgálatból. ${ }^{5}$

A 3147 települést felölelő, 6 csoportból álló klaszterstruktúra, amely statisztikailag is megállja a helyét (2. táblázat), már értelmezhetô a magyar települések rendszerében és az azokat leíró fókomponensekben tömörített információtartalom fényében.

A varianciaanalízisból kiderül, hogy a klaszterek ténylegesen szignifikánsan, markánsan elkülönülnek egymástól az azokat alkotó változók (fókomponensek) mentén (Székelyi-Barna, 2002), így a települések valós csoportokba tömörülnek. Azonban a különbözô fókomponensek igen eltérố mértékben járulnak hozzá a klaszterek egymástól történô elkülönüléséhez: az F-statisztika értéke nagyságrendileg alacsonyabb az 1. (szegénység és a rászorulókat támogató intézményrendszer; alapinfrastruktúra), az 5. (gazdasági versenyképesség, vállalkozások) és a 8 . (idôsek aránya, ellátása) fốkomponens esetében. A települési adatsorok tükrében ez nem is lehet másképp, hiszen ezek nagyrészt olyan demográfiai vagy gazdasági jellemzókből állnak, amelyek valamilyen értéket minden magyarországi település esetén felvesznek (a kiinduló koncepcióban ezek voltak a „külsố adottságok"), míg a többi fôkomponensben tömörülő közszolgáltatások egy nagy része csak bizonyos, az adott (al)központi funkcióval rendelkezô településeken találhatók meg, a többi településen pedig nulla az egyes változók értéke. Ez utóbbiak alkalmasabbak a típusképzésre, a közszolgáltatások szintjeinek és ezáltal a településhierarchia megragadására. 


\section{Tudományos múhely}

3. táblázat: A klaszteranalizis ellenôrzése egyutas varianciaanalizissel

\begin{tabular}{|c|c|c|c|c|c|c|}
\hline \multirow{2}{*}{ Fókomponens } & \multicolumn{2}{|c|}{ Klaszter } & \multicolumn{2}{|c|}{ Hiba } & \multirow[t]{2}{*}{ F érték } & \multirow[t]{2}{*}{$\begin{array}{c}\text { Szignifi- } \\
\text { kancia }\end{array}$} \\
\hline & $\begin{array}{l}\text { Varian- } \\
\text { cia }\end{array}$ & $\begin{array}{c}\text { Szab. } \\
\text { fok }\end{array}$ & $\begin{array}{l}\text { Varian- } \\
\text { cia }\end{array}$ & $\begin{array}{c}\text { Szab. } \\
\text { fok }\end{array}$ & & \\
\hline $\begin{array}{l}\text { 1. Szegénység, szoc. támogató } \\
\text { rendszer; alap-infrastruktúra }\end{array}$ & 7,54 & 5 & 0,99 & 3141 & 7,61 & 0 \\
\hline $\begin{array}{l}\text { 2. Óvodai ellátás, általános isko- } \\
\text { lai oktatás, körzeti eü. ellátás }\end{array}$ & 474,63 & 5 & 0,24 & 3141 & 1976,15 & 0 \\
\hline 3. Középfokú oktatás & 445,85 & 5 & 0,29 & 3141 & 1518,50 & 0 \\
\hline 4. Felsôoktatás & 500,63 & 5 & 0,21 & 3141 & 2422,18 & 0 \\
\hline $\begin{array}{l}\text { 5. Gazdasági versenyképesség, } \\
\text { vállalkozások }\end{array}$ & 3,22 & 5 & 0,28 & 3141 & 11,46 & 0 \\
\hline 6. Családok jóléte, jólléte & 398,61 & 5 & 0,37 & 3141 & 1087,44 & 0 \\
\hline 7. Kultúra, mobilitás & 184,59 & 5 & 0,36 & 3141 & 518,78 & 0 \\
\hline 8. Idôsek aránya, ellátása & 16,36 & 5 & 0,96 & 3141 & 17,10 & 0 \\
\hline
\end{tabular}

Forrás: Saját szerkesztés

4. táblázat: A kialakult végsố klaszterközpontok elhelyezkedése a fôkomponensek által meghatározott térben - az egyes klaszterek jellemzöi

\begin{tabular}{l|r|r|r|r|r|r}
\hline \multicolumn{1}{c|}{ „Faktortér": 6 klaszter a 8 dimenziós térben } & \multicolumn{7}{c}{ Klaszterek } \\
\hline \multicolumn{1}{c|}{ Fókonensek } & $\mathbf{1}$ & $\mathbf{2}$ & $\mathbf{3}$ & $\mathbf{4}$ & $\mathbf{5}$ & $\mathbf{6}$ \\
\hline $\begin{array}{l}\text { 1. Szegénység, szoc. támogató rendszer; } \\
\text { alap-infrastruktúra }\end{array}$ & $-0,34$ & $-0,20$ & $-0,27$ & 0,00 & 0,09 & 0,11 \\
\hline $\begin{array}{l}\text { 2. Óvodai ellátás, általános iskolai oktatás, } \\
\text { körzeti eü. ellátás }\end{array}$ & 0,10 & 0,21 & 0,24 & 0,80 & $-1,09$ & $-1,00$ \\
\hline 3. Középfokú oktatás & 1,14 & 3,06 & $-0,50$ & $-0,25$ & $-0,17$ & $-0,13$ \\
\hline 4. Felsốoktatás & 13,31 & $-0,13$ & $-0,27$ & $-0,03$ & $-0,04$ & $-0,04$ \\
\hline 5. Gazdasági versenyképesség, vállalkozások & 0,16 & 0,06 & 0,06 & $-0,05$ & $-0,08$ & 0,27 \\
\hline 6. Családok jóléte, jólléte & 0,74 & 0,94 & 2,60 & $-0,32$ & $-0,29$ & $-0,16$ \\
\hline 7. Kultúra, mobilitás & 0,04 & $-0,01$ & $-0,16$ & $-0,15$ & $-0,06$ & 2,97 \\
\hline 8. Idósek aránya, ellátása & $-0,05$ & $-0,02$ & 0,08 & 0,01 & 0,05 & $-0,88$ \\
\hline
\end{tabular}

Forrás: Saját szerkesztés

A kapott eredmények értelmezésében segítséget nyújtott az egyes fókomponensváltozók eloszlásának hisztogramos szemléltetése és elemzése, valamint klaszterenként általunk ismert példatelepülések beazonosítása, továbbá az eredeti (még nem standardizált) változók néhány településenkén- ti értékének vizsgálata is. A legfóbb ilyen változó a népességszám volt, amely mentén elég jelentôsen eltérnek az egyes klaszterek annak ellenére, hogy ez a mutató sem a fókomponens-, sem pedig a klaszterelemzésben nem szerepelt. A kialakult 6 klaszter a következôképpen interpretálható: 
5. táblázat: Az egyes klaszterekbe tartozó települések száma és az eredmények értelmezése

\begin{tabular}{|c|c|c|c|c|}
\hline Klaszter neve & $\begin{array}{l}\text { Telepü- } \\
\text { lések } \\
\text { száma }\end{array}$ & $\begin{array}{c}\text { Jellemzó } \\
\text { népességszám }\end{array}$ & $\begin{array}{c}\text { Közszolgáltatások jel- } \\
\text { lemzői }\end{array}$ & $\begin{array}{l}\text { A gazdaság és a tár- } \\
\text { sadalom jellemzói }\end{array}$ \\
\hline $\begin{array}{l}\text { 1. Felsőoktatás ál- } \\
\text { tal meghatáro-zott } \\
\text { települések }\end{array}$ & 14 & $\begin{array}{l}\text { Eltérố } \\
\text { népesség- } \\
\text { számú váro- } \\
\text { sok }\end{array}$ & $\begin{array}{l}\text { Mind az alap-, közép- és } \\
\text { felsôfokú intézmények- } \\
\text { kel, mind egyéb közszol- } \\
\text { gáltatásokkal jól ellátott } \\
\text { települések. }\end{array}$ & $\begin{array}{l}\text { Nagyszámú } \\
\text { vállalkozás, erós } \\
\text { gazdaság, magas } \\
\text { hozzáadott érték }\end{array}$ \\
\hline $\begin{array}{l}\text { 2. A viszonylagos } \\
\text { jólét gazdaságilag } \\
\text { stabil nagyközsé- } \\
\text { gei, városai }\end{array}$ & 217 & $\begin{array}{l}\text { Néhány ezer } \\
\text { fốtôl } 120 \text { ezer } \\
\text { fôig }\end{array}$ & $\begin{array}{l}\text { Alap- és középfokú } \\
\text { okatással és álalánosabb } \\
\text { jellegú szolgáltatásokkal } \\
\text { jól ellátott, de a felsốok- } \\
\text { tatás nem meghatározó. }\end{array}$ & $\begin{array}{l}\text { Általában viszony- } \\
\text { lag fejlett gazdaság, } \\
\text { a települések kö- } \\
\text { zött mezógazdasági } \\
\text { és ipari központok } \\
\text { is megtalálhatók. }\end{array}$ \\
\hline $\begin{array}{l}\text { 3. Viszonylag } \\
\text { gazdag, de gyak- } \\
\text { ran elöregedő } \\
\text { nagyobb községek }\end{array}$ & 229 & $\begin{array}{l}\text { Általában } \\
1-11 \text { ezer fö } \\
\text { között }\end{array}$ & $\begin{array}{l}\text { Alapfokú oktatással és } \\
\text { egészségügyi szolgáltatá- } \\
\text { sokkal jól ellátottak; kö- } \\
\text { zép- és felsôfokú oktatási } \\
\text { intézményekkel nem. }\end{array}$ & $\begin{array}{l}\text { Viszonylag feljett } \\
\text { gazdaság, amely } \\
\text { általában a me- } \\
\text { zógazdasághoz és } \\
\text { feldolgozóiparhoz } \\
\text { kapcsolódik. }\end{array}$ \\
\hline $\begin{array}{l}\text { 4. Kevéssé tehetôs } \\
\text { nagyobb községek }\end{array}$ & 1494 & $\begin{array}{l}\text { Jellemzően } \\
1000 \text { vagy né- } \\
\text { hányezer fố }\end{array}$ & $\begin{array}{l}\text { Alapfokú oktatással és } \\
\text { egészségügyi szolgáltatá- } \\
\text { sokkal jól ellátottak; kö- } \\
\text { zép- és felsôfokú oktatási } \\
\text { intézményekkel nem. }\end{array}$ & $\begin{array}{l}\text { A vállalkozások } \\
\text { száma és gazdasági } \\
\text { ereje még a népes- } \\
\text { ségre vetítve is igen } \\
\text { csekély. }\end{array}$ \\
\hline $\begin{array}{l}\text { 5. Viszonylag } \\
\text { szegény, általában } \\
\text { elöregedő kistele- } \\
\text { pülések }\end{array}$ & 1093 & $\begin{array}{l}\text { Néhány száz } \\
\text { fố }\end{array}$ & $\begin{array}{l}\text { Alap- és középfokú intéz- } \\
\text { mények és körzeti jellegú } \\
\text { közszolgáltatások csak } \\
\text { ritkán fordulnak elő. }\end{array}$ & $\begin{array}{l}\text { A vállalkozások } \\
\text { száma és gazdasági } \\
\text { ereje még a né- } \\
\text { pességre vetítve is } \\
\text { rendkívül alacsony. }\end{array}$ \\
\hline $\begin{array}{l}\text { 6. Szegény, elván- } \\
\text { dorlással sújtott } \\
\text { törpefalvak }\end{array}$ & 100 & $\begin{array}{l}100 \text { fó vagy az } \\
\text { alatt }\end{array}$ & $\begin{array}{l}\text { Sem az oktatás, sem az } \\
\text { egyéb, alapvetô közszol- } \\
\text { gáltatások nem érhetôk } \\
\text { el helyben. }\end{array}$ & $\begin{array}{l}\text { Az } 1000 \text { foóre jutó } \\
\text { gazdasági aktivi- } \\
\text { tás mutatója az } \\
\text { alacsony népesség- } \\
\text { szám miatt torzít, } \\
\text { nem értelmezhetô. }\end{array}$ \\
\hline
\end{tabular}

Forrás: Saját szerkesztés

Jellemzői alapján az egyik legkedvezóbb helyzetú csoport az 1. klaszter, amely az elsôsorban a felsôoktatás által meghatározott településeket foglalja magában. Ez a csoport népességszám alapján eltérô településeket tartalmaz, de egy kivétellel valamennyi város. Elemszáma mindössze 14 település, de igen kedvezó jellemzôik alapján elkülönülnek a többi öt klasztertól, valamint több mint 1 millió fôs lakosságot foglalnak magukban, az ország népességének 10,5\%-át. Így van értelme elkülönült típusként tekinteni rájuk. Ezeken a településeken nemcsak 
a felsôoktatás és a kulturális javakkal való ellátottság kiemelkedôen magas, de itt találhatók a legnagyobb számú és arányú, legerôsebb vállalkozások is. Nemcsak az oktatás, de valamennyi közszolgáltatással való ellátottságuk nagyon jó, a szegénység jelenléte ebben a településcsoportban a legkevésbé meghatározó. Korstruktúrájuk is kedvezô. Ebbe a településcsoportba tartozik például Pécs, Veszprém, Szeged Gödölló és Keszthely. Mindez alátámasztani látszik azt, hogy a felsőfokú oktatás és a K+F jelenléte és kiemelkedố színvonala (az alapvetôbb közszolgáltatások megléte mellett) általában pozitív hatással van a gazdaság egészére. (Persze a fordított irányú okság is jelen van.)

A 2. klaszter a "Viszonylagos jólét gazdaságilag stabil nagyközségei, városai" nevet kapta. 217 település került ebbe a csoportba, de a viszonylag nagy (néhány ezer fốtôl 120 ezres nagyságrendig) településméret miatt ez az ország népességének 30,6\%-át, körülbelül 3 millió fốt foglal magában. A településcsoport fó jellemzóje az, hogy közszolgáltatásokkal igen jól ellátott - bár a felsôoktatás és a kultúra arányaiban kevéssé meghatározó, nem elsósorban ez az ágazat adja a települések arculatát. Az elsô fókomponens, a szegénység alacsony (negatív) és a 6., családok jóléte fókomponens magas értéke stabilitásra enged következtetni. A népesség korösszetétele általában fiatal, nagyobb mértékú elvándorlás nem jellemzó. Ebbe a településkörbe tartozik például Tatabánya, Székesfehérvár, Kecskemét, Nagykanizsa, Villány, Hévíz és Bácsalmás.

A 3. klaszterbe ezer-tízezer fôs nagyközségek és kisebb városok tartoznak, összesen 229 település. (Összlakosságuk 1,3 millió fố, az ország népességének 13,5\%-a, átlagos népességük 5700 fó.) Ezeknek a falvaknak, illetve kisvárosoknak a lakosságára viszonylagos jólét jellemzó mind az 1. (szegénység hiánya), mind pedig a 6 . (családok jóléte) fókomponens mentén. Elvándorlás itt sem jellemzô, azonban a korstruktúra kedvezôtlenebb, a népesség gyakran elöregedô. Igen kedvezốn alakul a gazdasági társaságok 1000 fốre jutó száma, illetve a gazdaság fejlettsége. Ami a helyben elérhetô közszolgáltatásokat illeti, a települések jellemzốen igen jól ellátottak alapfokú oktatási intézményekkel, bölcsôdékkel, körzeti egészségügyi szolgáltatásokkal, de a középfokú oktatás már ritkábban található meg helyben, a felsôfokú oktatás jelenléte nem jellemzô. Összegezve, az idetartozó településeket általában nem nevezhetjük hátrányos helyzetúnek. (Idesorolható például Sarkad, Soltvadkert, Mecseknádasd és Lengyeltóti, valamint Budapest agglomerációjának számos települése.)

Mind az 1., mind pedig a 6 . fókomponens értékei alapján kevéssé tehetôs népességgel rendelkeznek a 4. klaszterbe tartozó nagyobb községek és néhány kisebb város. A kultúra, mobilitás fốkomponense is meglehetôsen alacsony értékeket mutat. Az ezer-néhány ezer fốs 1494 település Magyarország népességének 23,5\%-át (2,3 millió fốt) tömöríti. A települések gazdasági ereje jellemzóen csekély. Bár ezek a települések alapfokú oktatással, körzeti egészségügyi ellátással és alap-infrastruktúrával még viszonylag jól ellátottak, de a közép- és felsôfokú oktatási intézmények jelenléte nem meghatározó. A településcsoportba tartozik például Dunaalmás, Gyermely, Tiszabecs és Kurd.

A fentieknél kisebb népességszámú, jellemzốen néhány száz fốs, viszonylag 


\section{Tudományos múhely}

szegény, általában elöregedô kistelepüléseket az 5. klaszter foglalja magában. A családok jóléte-jólléte faktor (amely tartalmazza a bölcsốdei ellátási és bizonyos szociális ellátási mutatókat is) értéke itt a legalacsonyabb, de a szegénységet kifejezô 1 . fớkomponens értéke is kedvezôtlen. Ezek a települések alap- és középfokú oktatással, körzeti egészségügyi és egyéb közszolgáltatásokkal csak igen ritkán ellátottak (a csoport csak egy-egy településén található általános, illetve középiskola). Gazdasági erejük rendkívül alacsony, arányaiban és számában is kevés vállalkozás van jelen. Bár jellemzố az idôs korstruktúra, de az elvándorlás kevéssé. Idesorolható például Kisbajom, Gyulakeszi, Hunya és Tófalu. A csoport közel 400000 fốt, Magyarország népességének 3,9\%-át tömöríti.

A 6. klasztert gyakorlatilag a legszegényebb, közszolgáltatásokkal nem vagy alig ellátott, 100 fốs vagy az alatti törpefalvak alkotják. Az idesorolt 100 településen összesen kevesebb mint 8000-en élnek, azonban közszolgáltatásokkal való ellátatlanságuk gyakran a települések rossz elérhetôségével párosul, így esélyegyenlôségi szempontból fejlesztésüktől nem lehet eltekinteni. A csoport Borsod-Abaúj-Zemplén, Baranya és Zala megyében túlreprezentált. A kultúra, mobilitás fốkomponens magas értéke itt az elvándorlással magyarázható (tekintettel arra, hogy a kapcsolódó két változó, az állandó és az ideiglenes vándorlási egyenleg elôjele a fókomponens értékekkel ellentétes irányú), ami az érintett falvak szempontjából nem feltétlenül pozitív jelenség. 100 fớ alatti településeken a vállalkozások 1000 fớre jutó száma és a többi, hasonlóan képzett mutató sajnos nagyon torzít, az 5. fớkomponens magas értéke nagy valószínúséggel ennek tudható be, nem pedig tényleges gazdasági fejlettségnek. Ebbe a klaszterbe tartoznak például Salföld, Varga és Gagyapáti települések.

A 4. táblázatot tekintve, szembetúnô, hogy ahol a közszolgáltatások jellemzése pozitív, ott általában a gazdaságé is az, és viszont. Ez alól kivételt - a statisztikailag következetlen gazdasági mutatókkal jellemzett törpefalvak csoportját leszámítva - csak részben a 4. klaszter jelent, ahol az alapfokú oktatással és körzeti egészségügyi szolgáltatásokkal való ellátottság jónak mondható, ellenben a gazdaság igen fejletlen. (Ez azért csak részben igaz, mert a többi közszolgáltatás már hiányosabban képviselteti magát.) Mindez alátámasztani látszik azt az elképzelést, hogy a közszolgáltatások (és ezen belül a felsôoktatás és kultúra), valamint a gazdaság jelenléte egymást erősíti.

A fentiekben három olyan településcsoport volt azonosítható, ahol a jólét alacsony szintú, illetve hangsúlyosabban jelen van a szegénység, és a gazdaság sem fejlett (4., 5. és 6. klaszter, össznépességszámuk több mint 2,7 millió fố, az ország népességének 27,5\%-a 2687 településen. Ezeken a településeken vagy a közlekedés, mobilitás (térbeli és társadalmi értelemben egyaránt) elôsegítésére, vagy a lakosságot és a vállalkozási szférát is megcélzó közszolgáltatás-fejlesztésre van szükség. ${ }^{6}$

\section{ZÁRó GONDOLATOK}

A társadalmi jólét területi eloszlása és a gazdasági egyenlôtlenségek a magyarországi politikai rendszerváltoztatás idején átrendezôdtek. Ezt az átrendezôdést jellemzóen az iparszerkezeti struktúra megváltozása, részbeni leépülése okoz- 


\section{Tudományos múhely}

ta, amely bizonyos területeken gazdasági és társadalmi fejlódést eredményezett, ugyanakkor más területeken pedig ellentétes hatást váltott ki. Habár ennek kiindulópontja a gazdaság, a manifesztuma pedig a lakónépesség jólléte, de amint az a keresztmetszeti vizsgálat eredményéből is látszik, a folyamatok hosszú sorának multiplikátorhatása - akár a demográfiai, társadalmi vagy gazdasági szegmens vonatkozásában - máig kihat, és ezt a hatást erôsíti a lakónépesség közszolgáltatásokkal való ellátottságának mértéke. A dokumentumelemzések során egyértelmúvé vált, hogy a közszolgáltatások integrált megszervezése gyakorta fiskális nyomás eredménye, viszont ezzel együtt, ha a támogatási feltételek módosulnak, az ellátásokban minôségi változás következhet be.

A javasolt irány meghatározásának alapja az a feltételezés, hogy a növekedés szempontjából nem közömbös tény, hogy tetten érhetố egyfajta sứrúsödô elhelyezkedés, ami által a pozitív (a termelési költséget csökkentô) és a negatív (a termelési költségeket növelô, például ingatlanárak, bérleti díjak) externáliák különbözô kombinációit hívják életre.

A továbbiakban érdemes lenne megvizsgálni azt is, hogy ugyanezen változókat kiindulási változókként használva milyen eredményt adna a fókomponens-, illetve faktor- és klaszteranalízis járási szintre aggregálva (lásd Lukovics-Kovács hasonló vizsgálata, 2008). Ez a vizsgálat bizonyos szempontból árnyaltabb képet adna, hiszen belépnének a vizsgálatba olyan, települési szinten „dummy” voltuk miatt ezzel a módszerrel nem kezelhetô vagy kis számosságuk miatt kiesố változók is, mint például az ipari parkok száma, a vasútállomások léte vagy nemléte. Ezen túl a legerôsebb változókat kiragadva érdemes lenne regressziós elemzést is lefolytatni mind a települési, mind pedig a járási adatsorokon, amelynek magyarázó változói a demográfiai és egyéb helyi adottságok, a helyi köz- és egyéb szolgáltatások lennének, eredményváltozója pedig valamely, a gazdasági fejlettséget jól reprezentáló indikátor (pl. hozzáadott érték vagy jövedelem). Számos tanulsággal szolgálhatna néhány nagyobb, összefüggó területi egység (pl. megye) gazdasági, földrajzi, történeti dimenzióval kiegészített, összefüggéseiben történô, monografikus jellegú vizsgálata a közszolgáltatások gazdaságra gyakorolt hatása szempontjából. Egy késóbbi, átfogóbb vizsgálat keretében pedig kísérletet teszünk a tér- és idôtávok, valamint az idôdimenzió beépítésére is.

\section{JEGYZETEK}

1 Fogyasztásából nem zárható ki senki, és egy fogyasztó felhasználása nem csökkenti a rendelkezésre álló jószág mennyiségét (például levegô, víz, természeti környezet stb.).

2 Fogyasztásukból a kizárás megtörténhet, holott az ilyen jellegú szolgáltatás nem rivalizáló piacon múködik. Például a televíziós csatornák szolgáltatásainak egy bizonyos része ilyen: egy fogyasztó semmit nem veszít az élvezeti értékből, ha mások is nézik a szolgáltató ugyanazon músorát, viszont ha ugyanez a fogyasztó nem fizet elô a csatornára, kizárják a szolgáltatásból. Jó példa lehet erre a fizetős közutak esete is.

3 Erre láthattunk szép példát abból az idôből, amikor a helyi közlekedés önkormányzati finanszírozási hatáskörbe került, és Magyarországon három városban (Esztergom, Jászberény, Salgótarján) tagadta meg a közszolgáltatás ellátását a területileg illetékes szolgáltató, és az érintett városokban a munkába és iskolába járást a személygépjármû́vek megosztásával oldotta meg a lakosság.

4 Ezeket az ismert és elfogadott elméletekkel meg tudjuk erôsíteni. 


\section{Tudományos múhely}

5 Hasonló módszertanú, de eltérô cél- és szempontrendszerú, részben eltérô változókat felölelố elemzésben hasonlóképpen járt el Magyarország falutípusainak meghatározása során Beluszky Pál és Sikos T. Tamás is átfogó 1982-es és 2007-es vizsgálata során, amelyekbốl sokat merítettek a jelen tanulmány szerzôii.

${ }^{6} \quad$ Itt jegyzendô meg, hogy amennyiben a jelen tanulmány beépítette volna a közlekedési távolságokat, illetve többféle megközelíthetôségi mutatót az egyes társadalmi rétegek különbözô közlekedési lehetôségeit is figyelembe véve, a Dunántúl (különösen Vas, Zala és Baranya megyék) településeinek egy része feltehetôleg kedvezóbb klaszterbesorolásba esett volna a közeli (al)központ(ok) szolgáltatásai miatt. Tanulmányunk azonban a (szúkebb érelemben vett) helyi, települési szempontokat vette górcsố alá.

\section{FelHaSZnÁlt IRODALOM}

Beluszky Pál - Sikos T. Tamás (2007): Változó falvaink. MTA, Társadalomkutató Központ, Budapest.

Beluszky Pál - Sikos T. Tamás (1982): Magyarország falutípusai. MTA FKI, Budapest.

Bodnár, Gábor (2013): Endogenous Development: Role of Territorial Capital in Rural Areas. In: Lengyel, Imre - Vas, Zsófia (eds.): Regional Growth, Competitiveness and Development. University of Szeged, Faculty of Economics and Business Administration, Doctoral School in Economics, Szeged.

Bourdieu, Pierre (1980): Le capital social. Actes de la Recherche en Sciences Sociales, Vol. 31, 2-3.

Camagni, Roberto - Capello, Roberta (2009): Territorial Capital and Regional Competitiveness: Theory and Evidence. Studies in Regional Science, Vol. 39, 19-39, https://doi.org/10.2457/ srs.39.19.

Camagni, Roberto - Capello, Roberta (2013): Regional Competitiveness and Territorial Capital: A Conceptual Approach and Empirical Evidence from the European Union. Regional Studies, Vol. 47, No. 9, 1383-1402, https:// doi.org/10.1080/00343404.2012.681640.

Capello, Roberta - Fratesi, Ugo (2012): Modelling Regional Growth: An Advanced MASST Mo- del. Spatial Economic Analysis, Vol. 7, No. 3, 293-318, https://doi.org/10.1080/17421772 .2012.694143.

Chapain, Caroline - Clifton, Nick - Comunian, Roberta (2013): Understanding Creative Regions: Bridging the Gap between Global Discourses and Regional and National Contexts. Regional Studies, Vol. 47, No. 2, 131-134, https://doi.org/10.1080/00343404.2013.74 6441.

Coleman, James S. (1988): Social Capital in the Creation of Human Capital. The American Journal of Sociology, Vol. 94, Supplement: Organizations and Institutions: Sociological and Economic Approaches to the Analysis of Social Structure.

Farkas Zoltán (2013): A társadalmi tốke fogalma és típusai. Szellem és Tudomány, 4. évf., 2. sz., 106-133.

Hoffman István (2006): Önkormányzati közszolgáltatások szervezése és igazgatása. ELTE Eötvös Kiadó, Budapest.

Jóna György (2013): A területi tôke fogalmi megközelítései. Tér és Társadalom, 27. évf., 1. sz., 3051., https://doi.org/10.17649/TET.27.1.2449.

Káposzta József (2014): Területi különbségek kialakulásának fốbb összefüggései. Gazdálkodás, 58. évf., 5. sz., 399-402.

Kiss Norbert (2011): A minőségi közszolgáltatások hozzájárulása a versenyképességhez. Nemzeti Foglalkoztatási Szolgálat, Budapest.

Kovács Árpád (2007): Töredékek a versenyképességrôl a fenntartható fejlődésrốl és a fenntartható jogállamról. In: Lentner Csaba (szerk.): Pénzügypolitikai stratégiák a XXI. század elején. Akadémiai Kiadó, Budapest, 225-244.

Kovács Eszter (2016): A belföldi vándorlás alakulása és hatótényezôi Európában. Elôadás, Haza szolgálatában konferencia, Nemzeti Közszolgálati Egyetem, Budapest.

KSH (2015): Megyei statisztikai évkönyvek. Központi Statisztikai Hivatal, Budapest.

KSH (2017): Éves településstatiszikai adatok a 2015ös településszerkezetben. Tájékoztatási adatbázis. Területi Statisztika, KSH, Budapest.

Lentner Csaba (2007): A magyar nemzetgazdaság versenyképességének új típusú tényezôi. In: Lentner Csaba (szerk.): Pénzügypolitikai stratégiák a XXI. század elején. Akadémiai Kiadó, Budapest, 271-296. 


\section{Tudományos múhely}

Lukovics Miklós - Kovács Péter (2008): Eljárás a területi versenyképesség mérésére. Területi Statisztika, 11. évf., 3. sz., 245-263.

Miklós-Molnár Marianna (2012): A helyi önkormányzatok addicionalitásának biztosítása. PhD-értekezés, Budapesti Corvinus Egyetem, Budapest.

Nemes Nagy József (2009): Terek, helyek, régiók. A regionális tudomány alapjai. Akadémiai Kiadó, Budapest.

Nordhaus, William D. - Samuelson, Paul Anthony (2012): Közgazdaságtan. Akadémiai Kiadó, Budapest.

Obádovics Csilla (2009): Klaszteranalizis. Eszterházy Károly Főiskola, Eger.

Obádovics, Csilla - Buder, Emese - Kulcsár, László (2013): Territorial Inequalities of Economic and Welfare Situations in Rural Hungary - Similarities and Differences. In: Bódi, Ferenc Fábián, Gergely - Lawson, Thomas R. (eds.): Local Organization of Social Services in Hungary. Crises - Reactions - Changes. Europaeischer Hochschulverlag, Bremen, 163-178.

Palotai Dániel - Virág Barnabás (2016): Versenyképesség és növekedés. Magyar Nemzeti Bank, Válasz Könyvkiadó, Budapest.
Pénzes János (2013): A foglalkoztatottság, az ingázás és a jövedelmi szint összefüggései Északkelet- és Északnyugat-Magyarországon. Területi Statisztika, 53. évf., 3. sz., 202-224.

Rechnitzer János (2002): A városhálózat az átmenetben, a kilencvenes évek változási irányai. Tér és Társadalom, 16. évf., 3. sz., 169-189.

Sajtos László - Mitev Ariel (2007): SPSS kutatási és adatelemzési kézikönyv. Alinea Kiadó, Budapest.

Siska Miklós - Szabó Tamás (2015): Preferenciák a közlekedési mód megválasztásában Magyarországon. Tér - Gazdaság - Ember, 3. évf., 3. sz., 81-100.

Székelyi Mária - Barna Ildikó (2002): Túlélókészlet az SPSS-hez. Typotex, Budapest.

Tipold Ferenc - Jusztin Valéria - Pikler Katalin Kelenné Török Lívia - Magyar Judit - Kohán Zoltán - Tafferner Bálint (2015): A Közép-magyarországi régió esetleges kettéválasztásának lehetôségérôl szóló vizsgálat. Nemzetgazdasági Minisztérium, Budapest.

Varga Attila (2006): Térszerkezet, technológiai fejlódés és makrogazdasági növekedés. Dialóg Campus, Pécs.

Wallerstein, Immanuel (1983): Labor In The World Social Structure. SAGE Publications, London. 